\title{
Sagittal and Coronal Plane Fracture of Talar Body, An Unusual Combination with Medial Malleolus Fracture: A Case Report
}

\author{
Pankaj Kumar Singh ${ }^{1}$, Surendra Kumar Shukla ${ }^{2}$, Satish Chandra Goel ${ }^{1}$, Sachin \\ Yashwant Kale ${ }^{3}$, Rohit Mahesh Sane ${ }^{3}$
}

\section{Abstract}

Introduction: Fractures of the talus are relatively uncommon injuries with majority of them involving the neck region. Talar body fracture in sagittal plane in combination with medial malleolus fracture is very rare with few cases being reported in the literature earlier.

Aims and Objectives: To discuss such an unusual combination in an adolescent, which was treated with open reduction and internal fixation with screws for both talus and medial malleolus.

Materials and Methods: A 18-year-old boy with medial malleolus and sagittal plane talus fracture was treated with open reduction and internal fixation.

Conclusion: Talar body fractures in the sagittal plane and its combination with medial malleolus fracture are challenging due to its rarity and associated high degree of complications. Surgery should be planned at appropriate time considering the status of surrounding soft tissues and swelling. Proper anatomic reduction and rigid fixation with good surgical technique followed by cast immobilization and non-weight bearing for longer periods (at least 3 months or till radiological union) is the key to a good clinical outcome.

Keywords: Fracture, Talar body, Sagittal plane, Medial malleolus, Internal fixation

\section{Introduction}

Fractures of the talus are usually highenergy injuries and relatively uncommon accounting for $0.1 \%$ to $0.85 \%$ of all fractures [1]. More than $50 \%$ of all fractures involve the talar neck [2], and up to $25 \%$ of fractures involve the body of the talus [3]. Fractures involving the body of the talus are associated with complications such as ankle and subtalar osteoarthrosis and osteonecrosis. The combination of talar body fracture in the sagittal and coronal plane is an unusual pattern of injury and rarely reported in the literature [4-10]. Severity of injury, preservation of remaining precarious blood supply during surgery, quality of reduction and fixation and time of surgery since trauma predicts surgical outcome of such fracture. Medial malleolus fracture with intact deltoid ligament may preserve some amount of blood supply to talar body, also it provides natural window to exposure the Talus.
${ }^{1}$ Department of Orthopaedics, Heritage Institute of Medical Sciences, Varanasi, Uttar Pradesh, India,

${ }^{2}$ Department of Orthopaedics, K.J. Somaiya Medical College, Sion, Mumbai, Maharashtra, India,

${ }^{3}$ Department of Orthopaedics, D.Y. Patil University School of Medicine, Nerul, Navi-Mumbai, Maharashtra, India.

Address of Correspondence

Dr. Rohit Mahesh Sane,

Department of Orthopaedics, D.Y. Patil University School of Medicine, Nerul, Navi-Mumbai, Maharashtra, India. E-mail: dr.sanerohit@gmail.com

\section{Case Report}

An 18-year-old boy met with an accident by falling from ladder from height of approximately $10 \mathrm{ft}$. at home. His left foot being in inversion and dorsiflexion. He presented in the orthopaedic emergency ward after 2 days with a grossly swollen foot. The overlying skin was intact with no neurovascular deficit. Radiographs and CT scan revealed fracture of talus in the sagittal and coronal plane in association with vertical fracture of the medial malleolus (Figs. 1 and 2).

Surgical intervention was delayed to allow for the swelling to settle and soft tissues to recover, by limb elevation, ice packs, and anti-inflammatory drugs. Surgery was performed after 7 days of presentation. Talus was exposed through anteromedial approach and medial malleolus was carefully elevated along

| Journal of Clinical Orthopaedics | Available on www.jcorth.com | DOI:10.13107/jcorth.2021.v06i02.451 This is an Open Access article distributed under the terms of the Creative Commons Attribution NonCommercial-Share Alike 4.0 License (http://creativecommons.org/licenses/by-nc-sa/4.0) which allows others to remix, tweak, and build upon the work non-commercially as long as appropriate credit is given and the new creation are licensed under the identical terms. 


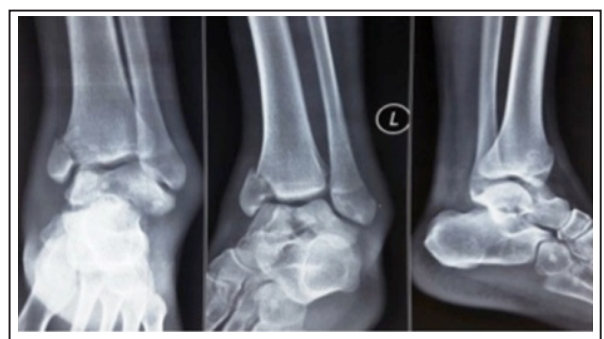

Figure 1: Antero-posterior, Oblique and lateral radiograph of left ankle showing fractures of talar body in sagittal plane and medial malleolus.

the fracture line and reflected distally preserving deltoid ligament. It was found that the fracture line had extended vertically involving the body of the talus (Figs. 3 and 4).

The body of the talus was reduced and fixed with k-wire. This was followed by fixation with Herbet's screws from medial to the lateral direction and then the neck of talus was reduced to the body and fixed with another Herbet's screw from anterior to posterior direction. Medial malleolus fragment was then reduced and fixed with $4 \mathrm{~mm}$ partially threaded cannulated cancellous screws (Fig.5). Meticulous wound closure done by Allgower Donati suturing technique in layers after thorough sterile wash.

Well padded dressing and a below knee POP slab was applied. The limb was elevated on a Bohler-Braun splint in the ward. First dressing was done after $24 \mathrm{~h}$ and subsequent dressing was done on post-operative day 4 . The patient was discharged after 7 days on a below knee slab and advised limb elevation, nonweight bearing. Sutures removal was

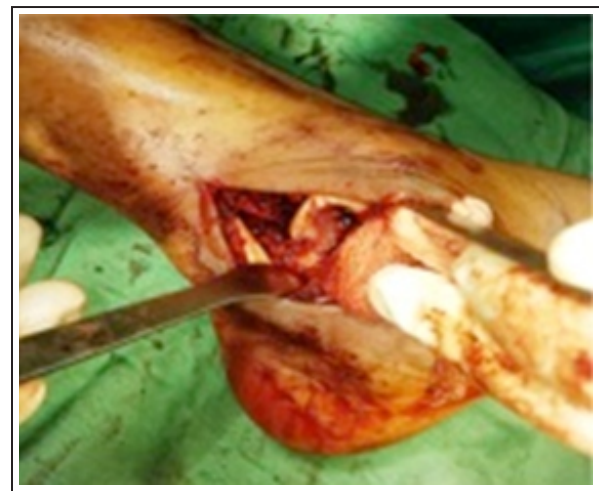

Figure 4: Intra operative views showing fracture reduction.

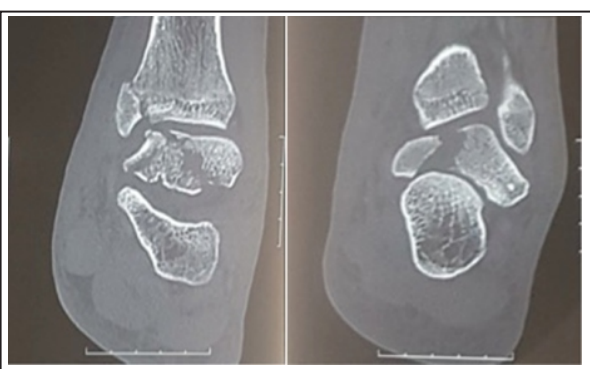

Figure 2: Computed tomography coronal section images ( $a$ and $b$ ) showing fracture pattern involving medial malleolus and talus.

done at 2 weeks, and a below knee fiber cast was given for a further period of 4 weeks. Non-weight bearing mobilization was allowed. After 1-month, cast was removed and aggressive exercises were started, but patient remained non-weight bearing for another 4 weeks (i.e. total 10 weeks).

This was followed by gradual weight bearing and continued exercises. Radiographs revealed union of fractures and no signs of avascular necrosis or secondary osteoarthritis (Figs. 6 and 7). At 1-year follow-up, range of motion gradually improved and it was equal to the opposite ankle (Figs. 8 and 9). Patient complained of occasional pain after prolonged standing or walking, but was otherwise highly satisfied with the surgical outcome.

\section{Discussion}

The outcome of talar body fractures is worse when compared to neck fractures, as the fracture neck of talus is extraarticular involving middle facet of the subtalar joint while body fractures are intra-articular involving both tibiotalar and subtalar joints [11]. Inokuchi et al.

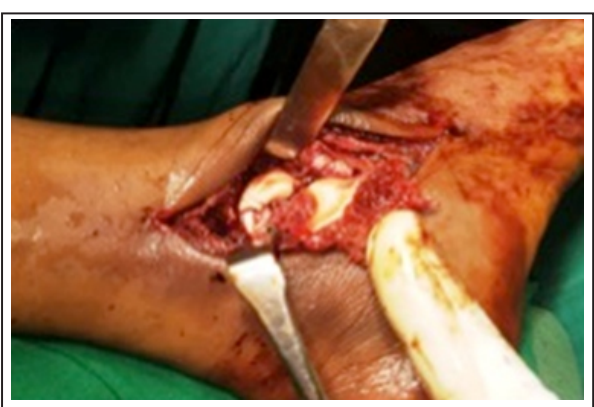

Figure 5: Intra operative views showing fracture fixation with screws.

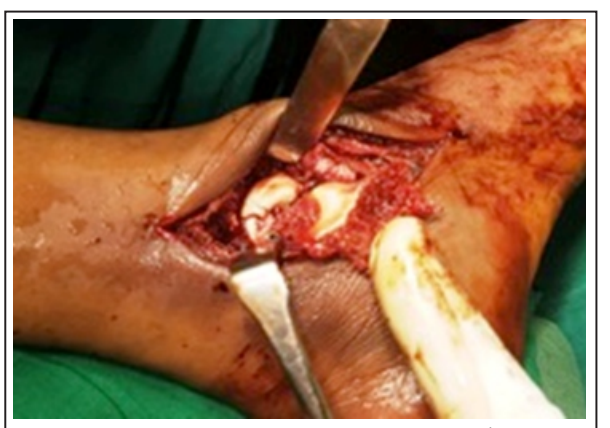

Figure 3: Intra operative views showing fracture fragments displacement.

defined talar body fractures as those in which fracture line on the inferior surface extends into the subtalar joint [12]. Sneppen et al. classified talar body fractures based on anatomic location into following types: Type A trans chondral or osteochondral, Type B coronal shear, Type $C$ sagittal shear, Type $D$ posterior tubercle, Type E lateral process, Type $\mathrm{F}$ crush injuries [13]. Furthermore, Boyd and Knight classification is used (Type I - coronal or sagittal shear fractures, Type II - horizontal shear fractures) [14]. These classifications are rarely used clinically and play little role in the management of these fractures.

The nature of injury in our case is likely to be a sagittal shear splitting talar body with fracture of talar neck and medial malleolus in near vertical direction, however, the mechanism of such injuries is not clear, but can be a combination of dorsiflexion with added axial compression, along with a supination element which fractures the medial malleolus [4]. Most of the previous studies have advised non-weight bearing for a minimum of 6-8 weeks; have

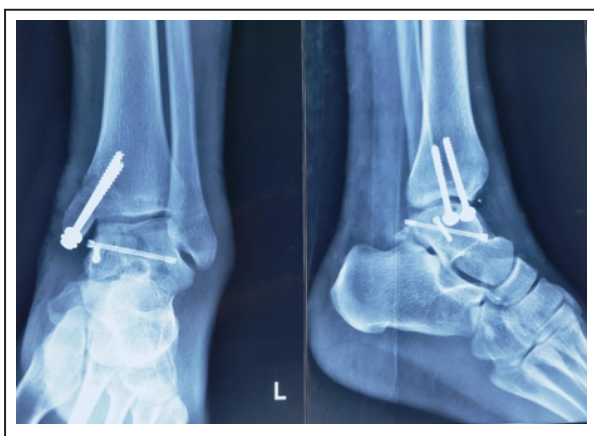

Figure 6: Anterior posterior and lateral $\mathrm{X}$ rays in the immediate post operative period. 


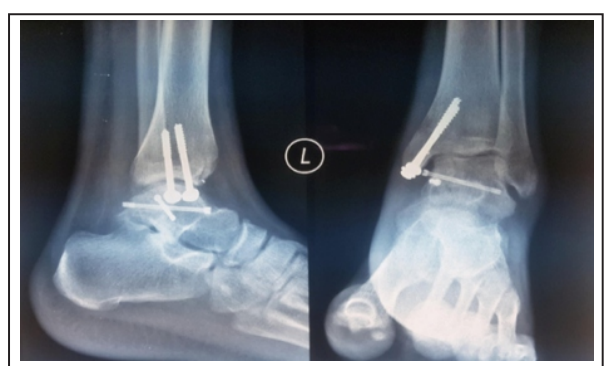

Figure 7: Post operatives X-rays at 10 weeks follow up.

reported good clinical outcomes with mild symptoms on follow up (Table 1 ). $\mathrm{CT}$ evaluation of such injuries should be done routinely to better define the fracture pattern and amount of displacement and comminution. Any displaced fracture should be treated with open reduction and internal fixation taking care to preserve the remaining precarious blood supply and aiming for anatomical congruous reduction of the articular surface. This congruous reduction of articular surfaces is to avoid complications. Medial malleolus fracture

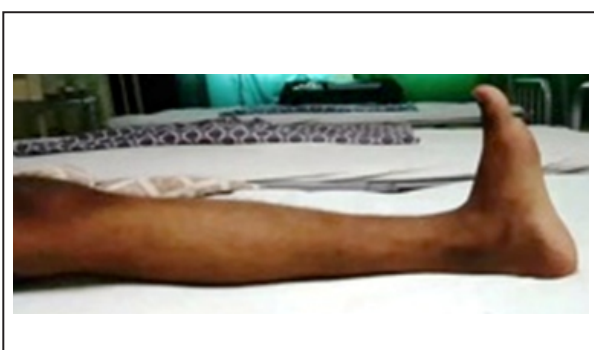

Figure 8: Clinical photo showing near normal range of motion in dorsi-flexion.

along with talar body fracture provides natural widow to the talus and may preserve some blood supply through its intact deltoid ligament branches of the posterior tibial artery to talar body. These fractures are slow to unite and may kept in below knee cast for longer time. Patient is advised not to bear weight till fracture unites.

\section{Conclusion}

Talar body fractures in the sagittal plane and its combination with medial malleolus fracture are challenging due to

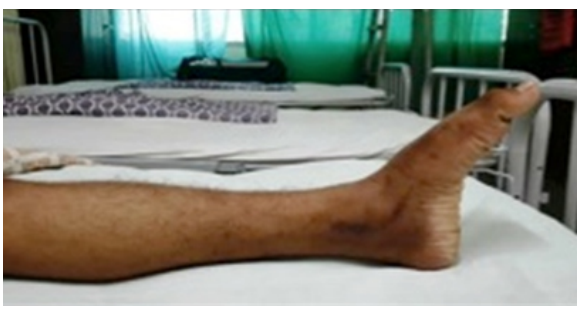

Figure 9: Clinical photo showing near normal range of motion in plantar-flexion.

its rarity and associated high degree of complications. Surgery should be planned at appropriate time considering the status of surrounding soft tissues and swelling. Proper anatomic reduction and rigid fixation with good surgical technique followed by cast immobilization and non-weight bearing for longer periods (at least 3 months or till radiological union) is the key to a good clinical outcome.

\begin{tabular}{|c|c|c|c|c|c|}
\hline Authors & Year & Pattern & Approach & Weight bearing & Outcome \\
\hline Mendonca et al . [4] & 2004 & $\begin{array}{l}\text { Talar body fracture in both sagittal and coronal } \\
\text { planes with intact neck, with medial malleolar } \\
\text { fracture }\end{array}$ & Anteromedial & $\begin{array}{l}\text { Non-weight bearing } \\
\text { for } 8 \text { weeks }\end{array}$ & $\begin{array}{l}\text { Full recovery with no evidence of AVN } \\
\text { at } 6 \text { months follow up }\end{array}$ \\
\hline Shahet al. [5] & 2004 & $\begin{array}{l}\text { Sagittal fracture of body with medial malleolar } \\
\text { fracture Talus fracture was undisplaced and } \\
\text { discovered intra-operatively }\end{array}$ & $\begin{array}{l}\text { Medial malleolus fixed from medial side } \\
\text { Talus fixed from lateral side (open or } \\
\text { percutaneous not mentioned) }\end{array}$ & Not mentioned & Not mentioned \\
\hline Laxman and Devalia [6] & 2006 & $\begin{array}{l}\text { Sagittal fracture of body with medial malleolar } \\
\text { fracture }\end{array}$ & Anteromedial & $\begin{array}{l}\text { Non-weight bearing } \\
\text { for } 3 \text { months }\end{array}$ & $\begin{array}{l}\text { Full ROM, with sclerosis of lateral } \\
\text { fragment and maintained joint space at } 14 \\
\text { year follow-up }\end{array}$ \\
\hline Saidi et al . [7] & 2008 & $\begin{array}{l}\text { Sagittal fracture of body with medial malleolar } \\
\text { fracture }\end{array}$ & Anteromedial & $\begin{array}{l}\text { Non-weight bearing } \\
\text { for } 3 \text { months }\end{array}$ & Good outcome, painless ankle at 6 months \\
\hline Isaacs et al . [8] & 2009 & $\begin{array}{l}\text { Talar body sagittal fracture and comminuted talar } \\
\text { neck fracture, with medial malleolar fracture }\end{array}$ & Dual medial and lateral approach & $\begin{array}{l}\text { Non-weight bearing } \\
\text { for } 7 \text { weeks }\end{array}$ & $\begin{array}{l}\text { Mild pain at } 12 \text { months; no AVN on } \\
\text { radiographs, but mild secondary } \\
\text { osteoarthritic changes in subtalar joint }\end{array}$ \\
\hline Mootha et al . [9] & 2010 & $\begin{array}{l}\text { Sagittal fracture of body with medial malleolar } \\
\text { fracture }\end{array}$ & Posteromedial & $\begin{array}{l}\text { Non-weight bearing } \\
\text { for } 6 \text { weeks }\end{array}$ & $\begin{array}{l}\text { Good outcome at } 3 \text { months with no } \\
\text { radiological signs of } \mathrm{AVN}\end{array}$ \\
\hline Mechchatet al . [10] & 2014 & $\begin{array}{l}\text { Sagittal fracture of body with medial malleolar } \\
\text { fracture }\end{array}$ & Anteromedial & $\begin{array}{l}\text { Non-weight bearing } \\
\text { for } 3 \text { months }\end{array}$ & $\begin{array}{l}\text { Little pain, mild secondary arthritis at } \\
\text { ankle, and good ROM } 14 \text { months follow- } \\
\text { up }\end{array}$ \\
\hline Arkesh et al. [15] & 2016 & $\begin{array}{l}\text { Sagittal fracture of talar body with medial } \\
\text { malleolar fracture }\end{array}$ & Anteromedial and Anterolateral & $\begin{array}{l}\text { Non-weight bearing } \\
\text { for } 12 \text { weeks }\end{array}$ & $\begin{array}{l}\text { Occasional pain on prolonged standing } \\
\text { with good ROM with just } 50 \text { loss of } \\
\text { terminal dorsi-flexion at } 6 \text { month follow } \\
\text { up }\end{array}$ \\
\hline
\end{tabular}

Declaration of patient consent: The authors certify that they have obtained all appropriate patient consent forms. In the form, the patient has given his consent for his images and other clinical information to be reported in the Journal. The patient understands that his name and initials will not be published, and due efforts will be made to conceal his identity, but anonymity cannot be guaranteed.

Conflict of Interest: NIL; Source of Support: NIL 


\section{References}

1. Fortin PT, Balazsy JE. Talus fractures: Evaluation and treatment. JAm Acad Orthop Surg 2001;9:114.

2. Hawkins LG. Fractures of the neck of the talus. J Bone Joint Surg 1970;52A:991-1002.

3. Adelaar RS. Fractures of the talus. In: Operative Foot Book. Philadelphia, PA: WB Saunders; 1990. p. 147-56.

4. Mendonca AD, Maury AC, Makwana NK. A simultaneous fracture of the tibia and talar body. Foot Ankle Surg 2004;10:457.

5. Shah K, Hakmi A. Unusual ankle injury a case report. Foot 2004;14:169-72.

6. Devalia KL, Ismaiel AH, Joseph G, Jesry MG. Fourteen years follow up of an unclassified talar body fracture with review of literature. FootAnkle Surg 2006;12:85-8.

7. Saidi H, Ayach A, Fikry T. Unusual fracture of the body of the talus: a case report and literature review. Foot Medicine and Surgery 2008;24:22-4.

8. Isaacs J, Courtenay B, Cooke A, Gupta M. Open reduction and internal fixation forconcomitant talar neck, talar body, and medial malleolar fractures: A case report. J Orthop Surg 2009;17:112-5.

Conflict of Interest: NIL

Source of Support: NIL
9. Mootha A, Kumar V, Bali K, Dhatt S, Aggarwal S. Combined talar body and medial malleolus fracture: A case report. Webmed Central Orthop 2010;1:WMC00952.

10. Mechchat A, Bensaad S, Mohammed S, Elibrahimi A, Elmrini A. Unusual ankle fracture: A case report and literature review. J Clin Orthop Trauma 2014;5:103-6.

11. Vallier HA, Nork SE, Benirschke SK, Sangeorzan BJ. Surgical treatment of talar body fractures. J Bone Joint Surg Am 2003;85:1716-24.

12. Ogawa K, Usami N. Classification of fractures of the talus: Clear differentiation between neck and body fractures. Foot Ankle Int 1996;17:748-50.

13. Sneppen O, Christensen SB, Krogsoe O, Lorentzen J. Fracture of the body of the talus. Acta Orthop Scand 1977;48:317-24.

14. Boyd HB, Knight RA. Fractures of the astragalus. South Med J 1942;35:160-7.

15. Arkesh M, Gaba S, Das S, Palanisamy JV, Trikha V. A rare combination of sagittal plane fracture of talar body with medial malleolus fracture: Case report and review of literature. J Clin Orthop Trauma 2016;7 Suppl 1:30-4.

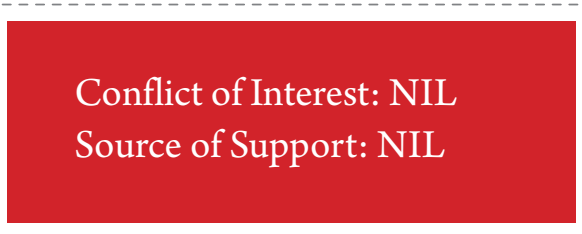

\section{How to Cite this Article}

Singh PK, Shukla SK, Goel SC, Kale SY, Sane RM. Sagittal and Coronal Plane Fracture of Talar Body, An Unusual Combination with Medial Malleolus Fracture: A Case Report. Journal of Clinical Orthopaedics July-Dec $2021 ; 6(2): 52-55$. 